THURSDAY, OCTOBER $25, \quad 1883$

\section{A SCIENTIFIC CATALOGUE}

Bibliotheca Historico-Naturalis et Mathematica. Lager Catalog von R. Friedlander und Sohn. (Berlin, I883.)

IKE enthusiastic physicians who are charmed with a L "splendid case"-of Asiatic cholera, it may bewhich illustrates or disproves some theory which has engaged their attention, there are philologists who are so interested in tracing the growth of variations among dialects by watching for and marking fresh changes in a parent language under different circumstances that they do not consider what an inconvenience this polyglot condition of society is, and what a length of time and amount of labour all but a gifted few have to expend in order to learn even three or four of the principal languages of ancient and modern times. Some considerations lead us to hope that, following many other benefits that scientific study has unweeningly brought to man, a unification of languages also may be in store.

As science spreads and makes way, the more indispensable to inquirers in each country becomes the knowledge supplied by the phenomena or the intellect in all others. Knowledge cannot be largely produced by a kind of secret manufacture of which one country or one race only knows the process. It must be patent in the older sense! Inductive science requires such a variety of observation of positive fact, and is so largely helped by comparison of working theories, that hardly any subject can be thoroughly studied without consulting both the facts noted by observers and the hypotheses started by philosophers in other countries. Commerce has, no doubt, brought a large number of men from many parts of the world into oral communication, but they are not of the class who have the means or the ambition to guide a language, as a majority of scientific writers are,-men who must largely control the education of their country.

But we have not arrived anywhere near the harbour of a common language yet. The first step has no doubt been taken by the agreement to use Greek roots for all scientific terms, so many of which keep forcing their way into familiar language through the utilitarian purposes connected with them; and science may claim its share also in the recent and increasing disuse of the old blackletter type by the Germans, and the adoption of the more general Arabic character - as in this publication, to which we are much pleased to call attention as a step towards counteracting the inconvenience now laboured under through the results of the tendency of languages to diverge. We have in England a fair sprinkling of libraries in which tolerably complete collections of English works are to be found, and the narrow boundaries of our crowded population make the use of them pretty practicable to the working student. But only a very few indeed of these contain at all complete collections of foreign publications; and, without doubt, the cosmopolitan studies of the Germans, their numerous universities-each, as Prof. Ray Lankester reminded the British Association, with a Government endowment sufficient at least to allow an earnest worker to follow up any pursuit which has raised his enthusiasm, and each as a VOL. XXVIII.-No. 730 matter of course engaged to some extent in original research-make their country the home and the market for such a collection of books as this. The special characteristic of this list is that it is restricted to science. The publisher was a successful student at the University of Berlin, where natural science was his favourite branch An American friend persuaded him to continue his studies at one of thd United States Universities. He made many friends there, but his father's death brought him back to Europe, and the large family of them which were left required him to give close attention to business. His knowledge, however, of science, and his connections in the United States, enabled him to get, and to execute with more than usual success, large orders for the different great libraries as they were successively founded there. He made it the work of his life to form as complete a collection as possible of all scientific books and publications, and the results are shown in this book, printed with a care which foreign writers would seldom find bestowed upon their names and upon the titles of their books in an English printed catalogue, and, although containing about $1250 \mathrm{pp}$., deserving to be classed as a handy volume. Nearly 50,000 entries of publications on science only are made, with the most full particulari as to illustrations, size, date, \&c. These are divided into 169 catalogues of works upon as many different subjects, upon which very elaborate classification we must remark that while no doubt suiting any consulters who only wanted a choice of books upon a subject, the dividing and classifying must add immensely to the labour expended upon it, and nevertheless reduce the value of the catalogue to the very students for whose benefit we are told that the compilation was made, viz. workers who wanted to know what upon each subject had been written in all scientific countries. For, as any one who glances down the index of subjects would see, there are very many books which are equally appropriate to half a dozen of them; and, since the same work is not repeated in list after list, it is necessary to consult an unknown number of them before the catalogue has answered the purpose intended. Of course it is difficult also to bring so general a list down to any date close upon that of publication, important as that is to all scientific writers especially, and the omissions which may be traced in this great collection are a striking evidence of the wealth of modern scientific literature.

\section{THE FISHERIES OF THE ADRIATIC}

The Fisheries of the Adriatic and the Fish thereof. A Report of the Austro-Hungarian Sea-Fisheries; with a Detailed Description of the Marine Fauna of the Adriatic Gulf. By G. L. Faber, Her Britannic Majesty's Consul, Fiume. (London: Bernard Quaritch, I883.)

O comprehensive work has till now appeared in English on the sea-fisheries of the Austro-Hungarian Empire, and though Mr. Faber modestly refers to his volume as a Report meant to pave the way for a more general work on the subject, yet we cannot but regard it as a very valuable history of the marine fauna and fishing interests of the Adriatic. The volume contains a systematic list of the fishes, including the freshwater forms of the watershed of the northern and eastern shores of the $\mathrm{n} \mathrm{D}$ 